\title{
EMPTY CEPHALOPOD CONCHS AS SUBSTRATES FOR GASTROPOD EGGS FROM THE HANGENBERG BLACK SHALE (LATE DEVONIAN) OF THE MAÏDER BASIN (MOROCCO)
}

\author{
CHRISTIAN KLUG ${ }^{1, *}$, ALEXANDER POHLE' ${ }^{1}$ DIETER KORN² \\ ${ }^{1}$ Paläontologisches Institut und Museum, Universität Zürich, Karl-Schmid-Strasse 4, 880006 Zürich, Switzerland; e-mail: chklug@pim.uzh.ch; \\ alexander.pohle@pim.uzh.ch. \\ ${ }^{2}$ Museum für Naturkunde Berlin, Invalidenstraße 43, 10115 Berlin, Germany; e-mail: dieter.korn@mfn-berlin.de. \\ * corresponding author
}

Klug, C., Pohle, A., Korn, D. (2019): Empty cephalopod conchs as substrates for gastropod eggs from the Hangenberg Black Shale (Late Devonian) of the Maïder Basin (Morocco). - Fossil Imprint, 75(1): 59-63, Praha. ISSN 2533-4050 (print), ISSN 2533-4069 (on-line)

\begin{abstract}
In the latest Famennian, black shale deposition occurred in many regions, some suggested a marine transgression as the explanation while others saw a link with higher organic input from the land. In either case, the Hangenberg Black Shale was most likely deposited under low oxygen conditions, which enabled exceptional fossil preservation in some regions such as the southern Maïder Basin of Morocco. Here, we provide the first account of small circular structures, in some cases with thin carbon films, which remained on ammonoid and bactritoid conchs. Due to similarities in their morphology and size with other occurrences documented from Europe, we propose that these structures may represent gastropod eggs. We also discuss whether egg-deposition occurred in the water column or on the sediment surface.
\end{abstract}

Key words: Ammonoidea, Bactritoidea, Vetigastropoda, Famennian, taphonomy, Konservat-Lagerstätte

Received: February 27, 2019 | Accepted: May 13, 2019 | Issued: August 29, 2019

\section{Introduction}

Mollusc eggs often lack mineralized shells and thus, they require exceptional conditions to become fossilized. Consequently, reports of non-mineralized egg cases of aquatic cephalopods and gastropods are scarce (Kaiser and Voigt 1977, 1983, Riegraf and Schubert 1991, Mikuláš and Dvořák 2001, Schubert et al. 2008, Etches et al. 2009, Zatoń et al. 2009, Mironenko and Rogov 2016). We describe two specimens with circular structures, which we interpret as gastropod eggs based on comparison with the material published in these articles. These fragile structures require a special taphonomic environment, which can usually be encountered in Konservat-Lagerstätten (Seilacher 1970).

The two fossil specimens presented here were excavated from the Hangenberg Black Shale equivalent in the Maïder (eastern Anti-Atlas, Morocco; for locality maps see Klug et al. 2016 or Frey et al. 2018, in press; further information: Korn 1999, Becker et al. 2000, 2018). During the Devonian, much of Morocco was covered by a more or less shallow epicontinental sea, situated at the northwestern edge of Gondwana and in the south-eastern bay of the Palaeotethys ocean at about $30^{\circ}$ south (Scotese 2014, Frey et al. 2018, in press). The Maïder-Basin was a small epicontinental basin with limited water exchange to the east and west, an island to the north and Gondwana to the south (e.g. Frey et al. in press). The limited water exchange with the neighboring Tafilalt Basin (Wendt 1985, 1988, Wendt and Belka 1991) is probably at least partially responsible for the repeatedly poor oxygenation of bottom waters during the Famennian (Frey et al. 2018, in press). Some authors suggest a short transgression during the latest Famennian (Haq and Schutter 2008) to explain black shale deposition in many localities worldwide including the Maïder Basin (Kaiser et al. 2011), but other hypotheses suggesting low oxygen conditions require further research. Even though the low oxygen content limited benthic life, it created favorable taphonomic conditions, because in addition to the low oxygen levels, the fine-grained argilites conserved organic structures such as non-mineralized cephalopod-mandibles (Klug et al. 2016), algae, regurgitates (Klug and Vallon 2019) as well as the structures described herein. The preservation of fragile organic structures and articulated skeletons qualify the Hangenberg Black Shale of the southern Maïder as a Konservat-Lagerstätte sensu Seilacher (1970). As demonstrated by Frey et al. (in press), it is remarkably similar in many respects to famous Black Shale Konservat-Lagerstätten sites such as Mazon Creek.

The aims of this paper are (1) to describe minute circular structures on Famennian cephalopod shells, (2) to discuss 
their biological origin and (3) to evaluate whether the cephalopod conchs were floating or resting on the sediment at the time of egg-laying.

\section{Circular structures on cephalopod conchs}

The Hangenberg Black Shale of Madene El Mrakib is usually deeply weathered and fresh pieces of sedimentary rocks are difficult to obtain. The two specimens presented here were excavated from a depth of about $0.5 \mathrm{~m}$ below the surface. Both slabs contain bivalves and cephalopods, but only two of the cephalopods bear the circular structures in question (Text-fig. 1).

PIMUZ 37326 is about $120 \mathrm{~mm}$ wide and shows a bright grey halo of oval shape, which measures $83 \times 55 \mathrm{~mm}$. It surrounds four macrofossils, namely a broken orthocone, two ammonoids (Mimimitoceras with a $26.5 \mathrm{~mm}$ diameter and a tornoceratid $15 \mathrm{~mm}$ in size; cf. Klug et al. 2016) and an incomplete gastropod (diameter $15 \mathrm{~mm}$ ). These macrofossils lie so close to each other that they must have touched. The orthocone was apparently broken, because the larger part (42 $\mathrm{mm}$ long) consists mainly of the body chamber and the last formed chambers while the other part is only a fragmentary phragmocone. The adapical diameter of the larger fragment ( $4 \mathrm{~mm}$ ) coincides perfectly with the adapertural diameter of the smaller fragment, they lie on top of each other and have the same apical angle (ca. $10^{\circ}$ ); thus, they probably belong to the same individual. The smaller fragment displays a longitudinal structure on one side with an irregular, light grey filling; we think that this is the ventral siphuncle and thus, the conch probably belonged to a bactritoid (previously reported by Klug et al. 2016). The body-chamber of the bactritoid shows seven circular impressions of identical size with a diameter of $1 \mathrm{~mm}$ (Text-fig. 1b). Their very narrow margins are imprinted into the bactritoid shell imprint (the shell is not preserved). No organic remains are preserved. All of the circular structures are situated in or on the body chamber.

The second specimen (PIMUZ 37325) contains slab and counterslab. The bedding plane shows a flattened Mimimitoceras with a diameter of $25 \mathrm{~mm}$, several bivalves of the genus Guerichia of various size and another small, undeterminable ammonoid (Text-fig. 1c). These fossils are loosely distributed over the bedding plane and do not touch each other. The flattened Mimimitoceras conch has fine growth lines or lirae preserved and the phragmocone appears slightly darker, possibly due to organic remains of the pellicle. In addition, it also displays eight subcircular dots on the former venter of the conch about $180^{\circ}$ behind the aperture, i.e. still within the body chamber. These circles carry a thin carbon film and their edges are also imprinted into the cephalopod, but it is impossible to determine whether they were on the outside or inside of the body chamber. In this case, the circular structures that can be measured have diameters of 0.5 to $0.8 \mathrm{~mm}$. Hence, they are somewhat smaller than those of PIMUZ 37325.

\section{What produced these structures?}

The circular structures described above lack morphological detail. However, they strongly resemble the fossil and recent structures described by, e.g. Zatoń et al. (2009), in their clustered arrangement (Zatoń et al. 2009: text-fig. 3$)$, their size range $(0.38$ to $1.2 \mathrm{~mm}$ in Zaton et al. 2009: tab. 2), their preservation state (carbon film only sometimes preserved), approximate number ( 2 to $>100$ in Zatoń et al. 2009: tab. 2) and incised margins (Zatoń et al. 2009: text-fig. 3). This suggests that the producers of these circular structures from the Jurassic and of those from the Devonian described here were related. We find the evidence provided by Zatoń et al. (2009) convincing and thus adopt the interpretation that these represent the remains of gastropod eggs.

However, there are alternative interpretations such as ostracod shells (Kröger 2013), which are also conceivable. They may also represent attachment scars of unknown organisms (e.g. algae).

In the Moroccan case (PIMUZ 37326), there is supporting evidence for the gastropod as producer: the bactritoid carrying the gastropod egg-cases is in close association with a gastropod. This raises the question as to the origin of the clustering of macrofossils in this case, which is discussed below.

\section{Were the cephalopod conchs afloat?}

Accepting that some sort of gastropod egg or other organism was attached to these cephalopod conchs, there are two alternative possibilities regarding when attachment occurred. Either attachment occurred when the cephalopod conchs had settled on the sediment surface or while the empty conch was afloat. This question is linked with the palaeoenvironmental conditions at the end of the Devonian at that time. The Hangenberg Black Shale of the southern Maïder Basin is characterized by laminated claystones with minute Chondrites burrows (Klug et al. 2016). Macrofossils often occur isolated but also in clusters of, e.g. bivalves and cephalopods. The lamination suggests that water movement was very limited due to a bathymetric position below the storm wave base. The question arises as to whether these clusters of macrofossils represent benthic islands (Seilacher 1982) or were floating structures, perhaps attached to algae (cf. Amler 2004). We do not have any evidence to

Text-fig. 1. Possible gastropod eggs from the Hangenberg Black Shale, latest Famennian, Madene El Mrakib (Morocco). a, b) PIMUZ 37326, cluster of two ammonoids and an orthocone (probably a bactritoid), surrounded by a light grey diagenetic halo: a) overview of the specimen with associated fossils (small ammonoids, bivalves and ? ostracods); b) detail of a to show the supposed gastropod egg capsules (arrows). c-e) PIMUZ 37325, Mimimitoceras with circular structures in organic (carbonized) preservation in or on the posterior body chamber: c) overview of the specimen with associated fossils (small ammonoids and bivalves of the genus Guerichia); d) detail of (c) showing the growth lines and the supposed gastropod egg capsules (arrows); e) enlarged detail of (d). 

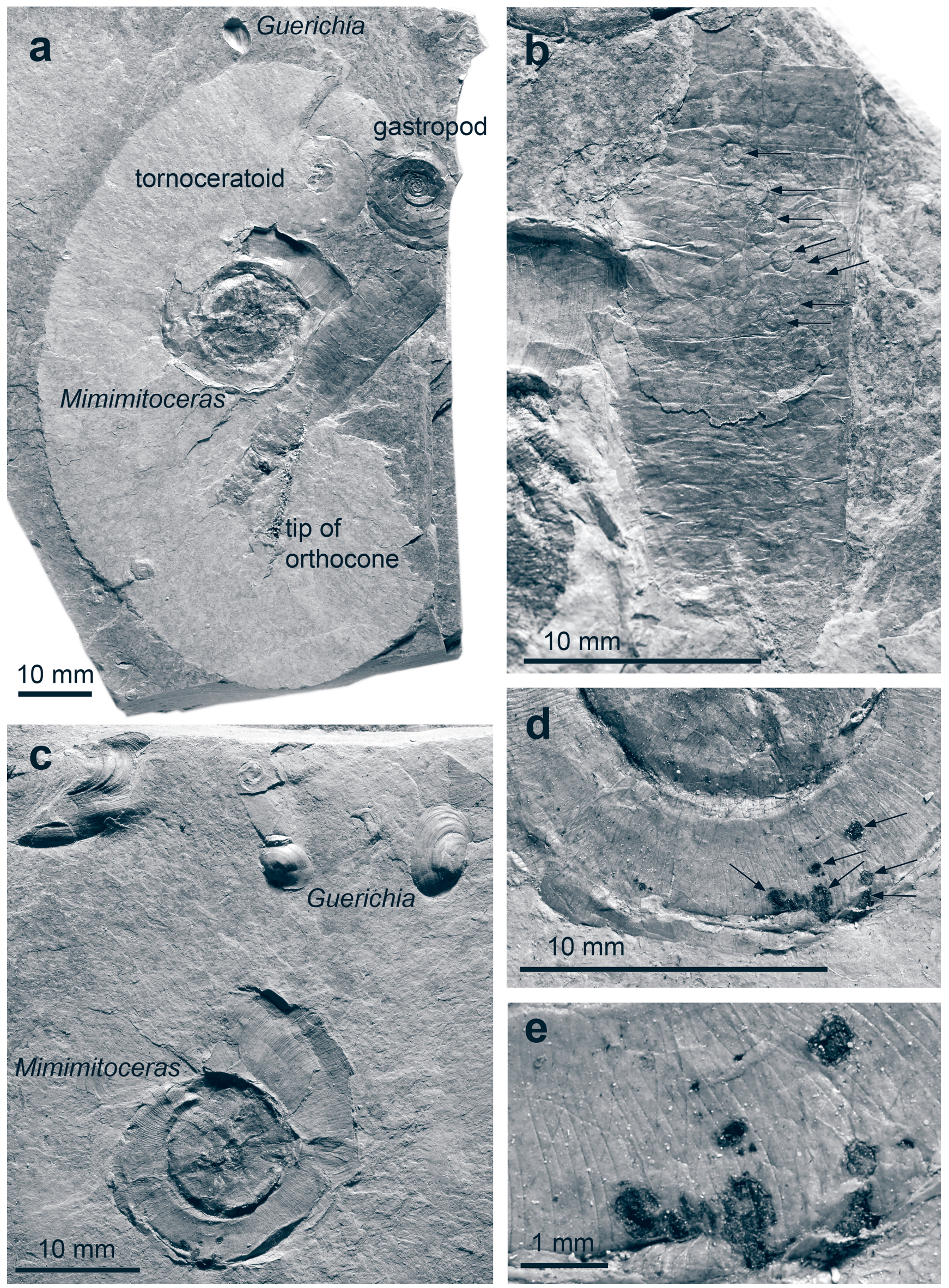
prove either of these two hypotheses, but we do have some indications supporting the second hypothesis.

Both ammonoid and bactritoid conchs most likely had a gas-filled phragmocone during the animal's lifetime providing them with approximately neutral buoyancy (e.g. Hoffmann et al. 2015, Naglik et al. 2016, Yacobucci 2018). For some time after their death, gas may have remained within the phragmocone, thereby facilitating floating. This does not apply to the associated bivalves and gastropods, of course. Amler (2004: 156) stated that Guerichia was an attached suspension feeder and possibly lived attached to floating algae. While this does not represent a hard evidence, algal remains are moderately abundant in the Hangenberg Black Shale. Chondrites can be seen as an indicator of low oxygen levels (e.g. Röhl et al. 2001, 2002), which is further supported by the absence of benthos such as brachiopods, corals or trilobites. Bryozoans occur occasionally, but only encrusting cephalopod conchs, which might have floated while the colony was alive. Hence, while we cannot fully prove that there was no benthic life that depended on normal oxygen levels, all the fossil organisms we found there so far may have floated (either attached as pseudoplankton or as real plankton) or swam actively (living cephalopods and chondrichthyans; Klug et al. 2016). We therefore suggest that the clusters of bivalves or cephalopods were perhaps floating for some time, maybe held together by algae (compare Nützel and Mapes 2001, Mapes and Nützel 2009). Nevertheless, these occurrences described here also resemble neritimorph egg capsules (Bandel 1982, Tan and Lee 2009) and thus might represent remains of eggs deposited on the conchs after they had settled on the seafloor. If the eggs were laid while afloat, the gastropods would have lived as holoplankton, a mode of life known only from Mesozoic and younger deposits (Nützel 2014, Nützel et al. 2016, Tajika et al. 2018); this renders the interpretation as eggs being deposited on a fossil raft somewhat unlikely. It is also conceivable that this happened in a shallower area, where oxygenation of bottom waters was normal and later, the conchs with the egg capsules were washed into these somewhat deeper parts of the basin.

\section{Conclusions}

We found circular imprints of 0.5 to $1 \mathrm{~mm}$ diameter on a bactritoid conch and an ammonoid conch from the Hangenberg Black Shale of the southern Maïder region. Due to their size, shape (imprinted margins), clustered occurrences and similarities to other fossil and recent occurrences, we interpret them as fossilized gastropod eggs.

In one case, these eggs are attached to a bactritoid that forms part of a cluster with two ammonoids and a gastropod. While the gastropod presence supports the interpretation that the occurrences were gastropod eggs, this clustering cannot be explained by stratinomic processes but rather by the possibility that shells of various mollusks formed rafts, possibly held together and afloat by algae. This is further corroborated by the black shale facies suggesting poor oxygenation and thus a low diversity benthos. However, other interpretations of these structures are possible and more material is needed to test this hypothesis.

\section{Acknowledgements}

We dedicate this article to Vojtěch Turek to honor his world class expertise in cephalopod palaeobiology in combination with his approachable friendly character. This field work was funded by the Swiss National Science Foundation (Project Number 200021_169627). The Ministère de l'Energie, des Mines, de l'Eau et de l'Environnement (Direction du Développement Minier, Division du Patrimoine, Rabat, Morocco) kindly provided working and sample export permits. Alexander Nützel (Munich) and Björn Kröger (Helsinki) reviewed the manuscript and provided constructive criticism.

\section{References}

Amler, M. (2004): Late Famennian bivalve, gastropod and bellerophontid molluscs from the Refrath 1 Borehole (Bergisch Gladbach-Paffrath Syncline; Ardennes-Rhenish Massif, Germany). - Courier Forschungs-Institut Senckenberg, 251: 151-173.

Bandel, K. (1982): Morphologie und Bildung der frühontogenetischen Gehäuse bei conchiferen Mollusken. Facies, 7: 1-198. https://doi.org/10.1007/BF02537225

Becker, R. T., Bockwinkel, J., Ebbighausen, V., House, M. R. (2000): Jebel Mrakib, Anti-Atlas (Morocco), a potential Upper Famennian substage boundary stratotype section. - Notes et Mémoires du Service géologique Maroc, 399: 75-86.

Becker, R. T., Hartenfels, S., Klug, C., Aboussalam, Z. S., Afhüppe, L. (2018): The cephalopod-rich Famennian and Tournaisian of the Aguelmous Syncline (southern Maïder). - Münstersche Forschungsberichte zur Geologie und Paläontologie, 110 (1): 273-306.

Etches, S., Clarke, J., Callomon, J. (2009): Ammonite eggs and ammonitellae from the Kimmeridge Clay Formation (Upper Jurassic) of Dorset, England. - Lethaia, 42: 204-217. https://doi.org/10.1111/j.1502-3931.2008.00133.x

Frey, L., Pohle, A., Rücklin, M., Klug, C. (in press): Fossil-Lagerstätten and preservation of vertebrates and invertebrates from the Devonian of Morocco (eastern Anti-Atlas). - Lethaia.

Frey, L., Rücklin, M., Korn, D., Klug, C. (2018): Late Devonian and Early Carboniferous alpha diversity, ecospace occupation, vertebrate assemblages and bio-events of southeastern Morocco. - Palaeogeography, Palaeoclimatology, Palaeoecology, 496 (1): 1-17. https://doi.org/10.1016/j.palaeo.2017.12.028

Haq, B. U., Schutter, S. R. (2008): A chronology of Paleozoic sea level changes. - Science, 322: 64-68. https://doi.org/10.1126/science.1161648

Hoffmann, R., Lemanis, R., Naglik, C., Klug, C. (2015): Ammonoid buoyancy. - In: Klug, C., Korn, D., De Baets, K., Kruta, I., Mapes, R. H. (eds), Ammonoid paleobiology, Volume I: From anatomy to ecology (Topics in Geobiology 43). Springer, Dordrecht, pp. 613-648. https://doi.org/10.1007/978-94-017-9630-9_16

Kaiser, P., Voigt, E. (1977): Über eine als Schneckenlaich gedeutete Eiablage in einer Schale von Pseudopecten 
aus dem Lias von Salzgitter. - Paläontologische Zeitschrift, 51: 5-11.

https://doi.org/10.1007/BF02986598

Kaiser, P., Voigt, E. (1983): Fossiler Schneckenlaich in Ammonitenwohnkammern. - Lethaia, 16: 145-156. https://doi.org/10.1111/j.1502-3931.1983.tb01710.x

Kaiser, S., Becker, R. T., Steuber, T., Aboussalam, Z. S. (2011): Climate-controlled mass extinctions, facies, and sea-level changes around the Devonian-Carboniferous boundary in the eastern Anti-Atlas (SE Morocco). - Palaeogeography, Palaeoclimatology, Palaeoecology, 310: 340-364. https://doi.org/10.1016/j.palaeo.2011.07.026

Klug, C., Frey, L., Korn, D., Jattiot, R., Rücklin, M. (2016): The oldest Gondwanan cephalopod mandibles (Hangenberg Black Shale, Late Devonian) and the Mid-Palaeozoic rise of jaws. - Palaeontology, 59 (5): 611-629. https://doi.org/10.1111/pala.12248

Klug, C., Vallon, L. H. (2019): Regurgitated ammonoid remains from the latest Devonian of Morocco. - Swiss Journal of Palaeontology, 138(1): 87-97. https://doi.org/10.1007/s13358-018-0171-z

Korn, D. (1999): Famennian Ammonoid Stratigraphy of the Ma'der and Tafilalt (Eastern Anti-Atlas, Morocco). - Abhandlungen der Geologischen Bundesanstalt, 54: 147-179.

Kröger, B. (2013): The cephalopods of the Boda Limestone, Late Ordovician, of Dalarna, Sweden. - European Journal of Taxonomy, 41: 1-110. https://doi.org/10.5852/ejt.2013.41

Mapes, R. H., Nützel, A. (2009): Late Palaeozoic mollusc reproduction: cephalopod egg-laying behavior and gastropod larval palaeobiology. - Lethaia, 42: 341-356. https://doi.org/10.1111/j.1502-3931.2008.00141.x

Mikuláš, R., Dvořák, Z. (2001): Fossil biogenic structures (? invertebrate eggs) attached to mollusc shells (Miocene; Northern Bohemian Brown Coal Basin, Czech Republic). - Journal of the Czech Geological Society, 46: 375-378.

Mironenko, A. A., Rogov, M. A. (2016): First direct evidence of ammonoid ovoviviparity. - Lethaia, 49: 245-260. https://doi.org/10.1111/let.12143

Naglik, C., Rikhtegar, F. N., Klug, C. (2016): Buoyancy in Palaeozoic ammonoids from empirical 3D-models and their place in a theoretical morphospace. - Lethaia, 49: 3-12. https://doi.org/10.1111/let.12125

Nützel, A. (2014): Larval ecology and morphology in fossil gastropods. - Palaeontology, 57(3): 479-503. https://doi.org/10.1111/pala.12104

Nützel, A., Mapes, R. H. (2001): Larval and juvenile gastropods from a Carboniferous black shale: palaeoecology and implications for the evolution of the Gastropoda. Lethaia, 34: 143-162. https://doi.org/10.1080/00241160152418447

Nützel, A., Schneider, S., Hülse, P., Kelly, S. R. A., Tilley, L., Veit, R. (2016): A new Early Jurassic gastropod from Ellesmere Island, Canadian Arctic - an ancient example of holoplanktonic gastropods. - Bulletin of Geosciences, 91: 229-242.

https://doi.org/10.3140/bull.geosci.1597

Riegraf, W., Schubert, S. (1991): Ein besonderes Fossil. Paläontologische Zeitschrift, 65: 227-229.

https://doi.org/10.1007/BF02989842
Röhl, A., Schmid-Röhl, H. J., Oschmann, W., Frimmel, A., Schwark, L. (2002): Palaeoenvironmental reconstruction of Lower Toarcian epicontinental black shales (Posidonia Shale, SW Germany): Global versus regional control. - Geobios, 35: 13-20. https://doi.org/10.1016/S0016-6995(02)00005-0

Röhl, H. J., Schmid-Röhl, A., Oschmann, W., Frimmel, A., Schwark, L. (2001): The Posidonia Shale (Lower Toarcian) of SW-Germany: An oxygen-depleted ecosystem controlled by sea level and palaeoclimate. - Palaeogeography, Palaeoclimatology, Palaeoecology, 165: 27-52. https://doi.org/10.1016/S0031-0182(00)00152-8

Schubert, S., Gründel, J., Nützel, A. (2008): Early Jurassic (Upper Pliensbachian) gastropods from the Herforder Liasmulde (Bielefeld, Northwest Germany). - Paläontologische Zeitschrift, 82: 17-30. https://doi.org/10.1007/BF02988430

Scotese, C. R. (2014): Atlas of Devonian Paleogeographic Maps, PALEOMAP Atlas for ArcGIS, vol. 4, The Late Paleozoic, Maps 65-72, Mollweide Projection, PALEOMAP Project, Evanston, IL.

Seilacher, A. (1970): Begriff und Bedeutung der Fossil-Lagerstätten. - Neues Jahrbuch für Geologie und Paläontologie, Monatshefte, 1970(1): 34-39.

Seilacher, A. (1982): Ammonite shells as habitats - floats or benthic islands? - In: Einsele, G., Seilacher, A. (eds), Cyclic and Event Stratification. Springer, Berlin, Heidelberg, pp. 504- 504 . https://doi.org/10.1007/978-3-642-75829-4_38

Tajika, A., Nützel, A., Klug, C. (2018): The old and the new plankton: ecological replacement of associations of mollusc plankton and giant filter feeders after the Cretaceous? - PeerJ, 6: e4219 (28 pp.). https://doi.org/10.7717/peerj.4219

Tan, K. S., Lee, S. S. C. (2009): Neritid egg capsules: are they all that different? - Steenstrupia, 30(2): 115-125.

Wendt, J. (1985): Disintegration of the continental margin of northwestern Gondwana: Late Devonian of the eastern Anti-Atlas (Morocco). - Geology, 13: 815-818. https://doi.org/10.1130/0091-7613(1985)13<815:D OTCMO $>2.0 . \mathrm{CO} ; 2$

Wendt, J. (1988): Facies pattern and palaeogeography of the Middle and Late Devonian in the eastern Anti-Atlas (Morocco). - In: Mc Millan, N. J., Embry, A. F., Glass, D. J. (eds), Devonian of the World, I. Canadian Society of Petroleum Geologists, Calgary, pp. 467-480.

Wendt, J., Belka, Z. (1991): Age and depositional environment of Upper Devonian (early Frasnian to early Famennian) black shales and limestones (Kellwasser facies) in the eastern Anti-Atlas, Morocco. - Facies, 25: 51-90. https://doi.org/10.1007/BF02536755

Yacobucci, M. M. (2018): Postmortem transport in fossil and modern shelled cephalopods. - PeerJ, 6: e5909 (20 pp.). http://doi.org/10.7717/peerj.5909

Zatoń, M., Niedźwiedzki, G., Pieńkowski, G. (2009): Gastropod egg capsules preserved on bivalve shells from the Lower Jurassic (Hettangian) of Poland. - PALAIOS, 24: $568-577$. https://doi.org/10.2110/palo.2009.p09-005r 